\title{
Introducing Some Traumas and PTSD among Yazidi Female Survivors from ISIS Army
}

\author{
Nazdar Qudrat Abas \\ MSc. Psychiatric Mental Health Nursing \\ Psychology Department/ College of Education/ University of Garmian \\ nazdar.qudrat@garmia.edu.krd
}

\begin{abstract}
Background: The violence against women remains one of the most serious challenges of our times. Sexual violence committed in armed conflicts has been termed "history's greatest silence" is considered to be a central issue and a "top priority" in the work of the worldwide governments. The discrimination and the sexual abuse of Yazidi women and girls by the terrorist group ISIS in august 2014 in Sinjar is a horrible war crime against Yazidi people and an international tragedian crime in this era. Yazidi people especially their females have been through lots physical and psychological traumas since ISIS attack, as a result of these and other violence acts they are exposed to physical problems and serious mental illnesses such as PTSD, depression and suicide, sleep disorders and eating disorders. The study aims to spot the light on some of the traumas that Yazidi female survivors faced with ISIS and to measure the prevalence of PTSD among the survivor Females. Method: a descriptive study with purposive sampling of (52) Yazidi female survivors from ISIS have given the study questionnaire, which composed of some sociodemographic and general questions, and PTSD questionnaire, from September to November 2016, in Yazidi camps in Duhok. A descriptive statistics was used to describe the results by (SPSS. 22). Results: the results have shown high percentages of the traumas that is faced by Yazidi female survivors, (38.4) have hardly escaped from ISIS militants, (80.7) have lost at least one member of their families, (76.9) exposed to physical violence, (61.5) exposed to sexual violence, (84.6) exposed to violence by more than one person, and (75.0) of them have PTSD symptoms. Recommendations: national and international interventions are required for them especially for the victims of sexual violence, physical, social and psychological supports are needed. Further studies and researches also required to assess their suffering and other possible psychological disorders.
\end{abstract}

Keywords: ISIS, trauma, PTSD, yazidi female survivors. 


\section{Introduction}

The Islamic state' (ISIS) swept attacks in north of Iraq in $3^{\text {rd }}$ of August 2014, against Yazidi people in Sinjar, Thousands of Yazidi people were displaced, about (340000) were displaced from Sinjar, and (60000) from related villages, (1300) was murdered in the same day, more than (6413) were taken to captivity, (3547) females and (2870) males. To this end, only (3001) of them have been released, (1077) women, (334) men, (800) female children, and (790) male children. Despite local and international attempts to help Yazidies in captivity and release them, ISIS army still have (3416) of Yazidies, (1670) females, and (1746) males. More than (90000) of Yazidies have migrated to outside of Iraq (Buzany, 2017, UN HRC, 2017).

Rape continues to be used as a tactic not only of war, but, indeed, of genocide, ISIS has used gender-based violence as a weapon of their war and a tool of horror and genocide (McCausland, 2017; Chanda, 2016). ISIS performed extreme forms of violence against a small, ancient ethnoreligious group, the Yazidis. Yazidi women and girls from different areas were kidnapped with their families, then separated the women and girls from their families, and murdered the men. ISIS militants use the most unhuman methods of violence against Yazidi women and girls, they use physical, sexual, and psychological abuses toward them and their families, they treat them like property, calling them Sabaya — "war spoils" and selling them in the markets like properties (Hassen, 2016). According to a recent Human Rights Watch (HRW) report, ISIS is still holding thousands of Yazidi women and children in slavery and this far about (1100) Yazidi women and girls to safety and for medical and psychological treatment in Germany (Davis, 2016).

Yazidi women and girls have been through lots of psychological traumas and violence in a very short time, and these traumas and violence still happening toward many of them. In this case, the Yazidi women and girls are at a high risk for post-traumatic stress disorder (PTSD), in 1980, for the first time the American Psychiatric Association (APA) added PTSD to the third edition of its Diagnostic and Statistical Manual of Mental Disorders (DSM-III) (Wilson et al, 2012; Friedman, 2014). PTSD is a general anxiety disorder that can occur following the experience or witnessing of a traumatic event, People with PTSD experience three different kinds of symptoms. The first set of symptoms involves reliving the trauma in some way such as becoming upset when confronted with a traumatic reminder or thinking about the trauma when you are trying to do something else. The second set of symptoms involves either staying away from places or people that remind you of the trauma, isolating from other people, or feeling numb. The third set of 
symptoms includes things such as feeling on guard, irritable, or startling easily, some common symptoms include, but are not limited to, intense fear, reliving the experience, persistent avoidance, numbing, diminished interest, and increased arousal, flashbacks. (Carrion et al 2002). In order to be diagnosed, these symptoms need to be present for more than one month and the person have them for six months after the trauma. Subsequently there are many types of treatment for this disorder (Asmundsin et al 2009), treatments include drug therapies (TCAs, carbamazepine, MAOIs, SSRIs, and BDZs), psychological therapies (behavior therapy, EyeMovement Desensitization and Reprocessing (EMDR), relaxation training, hypnotherapy, and dynamic therapy), and control conditions (pill placebo, wait-list controls, supportive psychotherapies, and non-saccade EMDR control) (Van Etten \& Taylor, 1998). A traumatic event is a life-threatening event such as military combat, natural disasters, terrorist incidents, serious accidents, or physical or sexual assault in adult or childhood. Most survivors of trauma return to normal given a little time. However, some people will have stress reactions that do not go away on their own, or may even get worse over time; these individuals may develop PTSD (Andrykowski, et al, 1998). The exposure must result from one or more of the following scenarios, in which the individual: - directly experiences the traumatic event; - witnesses the traumatic event in person; - learns that the traumatic event occurred to a close family member or close friend (with the actual or threatened death being either violent or accidental); or • experiences first-hand repeated or extreme exposure to aversive details of the traumatic event (not through media, pictures, television or movies unless work-related). The disturbance, regardless of its trigger, causes clinically significant distress or impairment in the individual's social interactions, capacity to work or other important areas of functioning. It is not the physiological result of another medical condition, medication, drugs or alcohol (Gupta, 2013). PTSD is associated with serious consequences that may lead to poor quality of life and increased use of health and other social services. Duration of PTSD symptoms may, therefore, serve as an indicator of the impact of the condition on an individual's life (Atwoli et al, 2015). This subject has been studied by other researchers as well, Breslau et al (1998) estimated the relative importance of specific types of traumas experienced in the community in terms of their prevalence and risk of leading to posttraumatic stress disorder (PTSD), and they found that the risk of PTSD associated with a representative sample of traumas is less than previously estimated. Shalev et al (1998) conducted the prospective study of posttraumatic stress disorder and depression following trauma, they discovered that Major depression and PTSD are 
independent sequelae of traumatic events, have similar prognoses, and interact to increase distress and dysfunction. Brewin et al (2000) made a study about Meta-analysis of risk factors for posttraumatic stress disorder in trauma-exposed adults, Meta-analyses were conducted on 14 separate risk factors for posttraumatic stress disorder (PTSD), and the moderating effects of various sample and study characteristics, including civilian/military status, were examined, the effect size of all the risk factors was modest, but factors operating during or after the trauma, such as trauma severity, lack of social support, and additional life stress, had somewhat stronger effects than pre-trauma factors. Ozer et al (2003) applied a meta-analysis study about predictors of posttraumatic stress disorder and symptoms in adults, they reviewed 2,647 studies of posttraumatic stress disorder (PTSD), they found common 7 predictors: (a) prior trauma, (b) prior psychological adjustment, (c) family history of psychopathology, (d) perceived life threat during the trauma, (e) posttrauma social support, (f) peritraumatic emotional responses, and (g) peritraumatic dissociation, and also they suggest that peritraumatic psychological processes are the strongest predictors of PTSD. Scott et al. (2013) have demonstrated in a large cross-national study that trauma exposure itself has downstream effects on physical health independent of PTSD effects. The effect was linked to the number of traumatic events an individual was exposed to, with exposure to four or more traumatic events being associated with a wide range of chronic psychological and physical conditions including arthritis, back and neck pain, frequent or severe headaches, heart disease, high blood pressure, asthma, peptic ulcers, chronic lung disease, and stroke. Mancini (2016) studied the Fury of ISIS Against Ethnic and Religious Minorities: The Genocide of the Yazidis, the study focuses on the atrocities that the Yazidis have been suffering at the hands of ISIS in Iraq and Syria, since August 2014, and ISIS fighters intended to destroy them, in whole or in part. Moller et al (2017), studied Tonic immobility during sexual assault - a common reaction predicting posttraumatic stress disorder and severe depression, they found tonic immobility during rape is a common reaction associated with subsequent posttraumatic stress disorder and severe depression.

According to psychiatric and psychology references, researches, and books, more than two thirds of persons in the general population may experience a significant traumatic event at some point in their lives (Galea et al, 2005) and any person once exposes to a trauma like rape or kidnapping, or witnesses a trauma like accidents, war, explosions, there will be a great possibility to cause serious psychological problems and/ or mental disorders especially PTSD and depression. 
(Johnson \& Thompson, 2008) Yazidi people, especially their women and girls have been exposing too many different types of trauma since ISIS militants' attack. ISIS army have murdered the men, destroyed their homes, displaced thousands of them, used the women and girls like slaves (Sabaya), they sell them in markets like property, and they rape and torture them. To whom they still in captivity the traumas are still happening every day. In this case, Yazidi women and girls are at a very dangerous level of suffering, and lots of serious mental disorders are possible among them. It's important to spot the light on some of the common traumas that the survivors of Yazidi women and girls have been through during the time they spent in captivity and also because there are no local studies about Yazidies women especially in Kurdistan region, national and international powers have not yet been able to meet their demands properly, so conducting such work was to be very necessary. After explaining the sufferings of Yazidies, introducing PTSD and other traumas, and the previous studies, the present study aims to spot a new light on the PTSD conditional risk associated with specific traumatic events that survivors of Yazidi females faced with ISIS and to measure the prevalence of PTSD among the survivor Females.

\section{Material and Methods:}

A descriptive study design was used for the purpose of the study to describe the traumas and PTSD level among the survivors of Yazidi females, a purposive sampling was used to collect data from (52) Yazidi female survivors from ISIS militants after they have spent some time in captivity, because women are more likely than men to have PTSD after disasters (Carr et al, 1995). The (52) females were given the study questionnaire, which composed of two parts: part one composed of some socio-demographic data like age, and some questions about methods of surviving from ISIS militants, missing members of the family, assessing the physical and sexual violence, and if the violence was made by one person or more. The second part of the questionnaire composed of a standard PTSD questionnaire, which composed of (17) questions related to PTSD symptoms with Likert's five measuring scales for each question $($ Never $=0$, Rarely $=1$, Sometimes $=2$, Often $=3$, and Very Often $=4)$, and the scores were as follow: $(0-22)$ no or mild symptoms of PTSD, (23-45) possibility of PTSD, (46 \& more) most of PTSD symptoms (Lang \& Stein, 2005; Lang et al, 2012; Grohol, 2016). The questionnaire was translated into Arabic language and offered to psychology and language professional for linguistic validation. The data collection started from the begging September to the end of 
November 2016, in Yazidi camps in Duhok governorate, Kurdistan region by the help of the Yazidi organizations in the area. A descriptive statistics of frequency, percentage, mean and standard deviation was used to describe the results of the study by the (SPSS. 22).

\section{Results:}

The present study has got some results as follow:

Table (1): frequency distribution of the samples' age groups:

\begin{tabular}{|c|c|c|c|c|}
\hline Age groups & Frequency $(\mathbf{F})$ & Percentage (\%) & Mean & Std. \\
\hline $18->29$ & 29 & 55.7 & \multirow{4}{*}{28.5} & \multirow{4}{*}{8.20} \\
\hline $29->39$ & 18 & 34.6 & & \\
\hline $39 \&$ more & 5 & 9.6 & & \\
\hline Total & 52 & 100.0 & & \\
\hline
\end{tabular}

The table shows the samples' age groups, the age (18->29) have reported higher frequencies compared to other age groups.

Table (2): frequency distribution of salvation methods by the survivors:

\begin{tabular}{|l|l|l|}
\hline salvation methods & F & \% \\
\hline Escape & 20 & 38.4 \\
\hline Redemption & 25 & 47.07 \\
\hline Helped by someone & 7 & 13.4 \\
\hline Total & 52 & 100.0 \\
\hline
\end{tabular}

The table shows that the higher frequencies are for the redemption and escape (47.07) and (38.4) accordingly.

Table (3): frequency distribution of having lost family members:

\begin{tabular}{|l|l|l|}
\hline lost members & F & \% \\
\hline Having lost members & 42 & 80.7 \\
\hline No lost members & 10 & 19.2 \\
\hline Total & 52 & 100.0 \\
\hline
\end{tabular}

The table shows a very high percentage (80.7) of lost members in the families of the survivors. 
Table (4): frequency distribution of violence types:

\begin{tabular}{|l|l|l|l|l|l|l|}
\hline \multirow{2}{*}{$\begin{array}{l}\text { Type of } \\
\text { violence }\end{array}$} & Yes & No & Total \\
\cline { 2 - 7 } & F & \% & F & \% & F & \% \\
\hline Physical & 40 & 76.9 & 12 & 23.07 & 52 & 100.0 \\
\hline Sexual & 32 & 61.5 & 20 & 38.4 & 52 & 100.0 \\
\hline
\end{tabular}

The physical violence has somehow a higher percentage (76.8) than the sexual violence (61.5).

Table (5): frequency distribution of violence directors (assaulters):

\begin{tabular}{|l|l|l|}
\hline Number of Assaulters & F & \% \\
\hline One Assaulter & 8 & 15.3 \\
\hline More than One Assaulter & 44 & 84.6 \\
\hline Total & 52 & 100.0 \\
\hline
\end{tabular}

Numbers of assaulters, the majority of the sample (84.6) were exposed to violence from more than one assaulter.

Table (6): frequency distribution of PTSD symptoms among the sample:

\begin{tabular}{|c|c|c|c|c|}
\hline PTSD symptoms & $\mathbf{F}$ & $\%$ & Mean & Std. \\
\hline $\begin{array}{l}\text { No enough PTSD symptoms } \\
(0-22)\end{array}$ & 3 & 5.7 & \multirow{4}{*}{47.65} & \multirow{4}{*}{11.23} \\
\hline $\begin{array}{l}\text { Possible PTSD symptoms } \\
(23-45)\end{array}$ & 10 & 19.2 & & \\
\hline $\begin{array}{l}\text { Have lots of PTSD symptoms } \\
(46-68)\end{array}$ & 39 & 75.0 & & \\
\hline Total & 52 & 75.0 & & \\
\hline
\end{tabular}

The majority of the sample (75.0) has PTSD symptoms, and only (5.7) showed no symptoms.

\section{Discussion:}

The current study aimed to spot a light on the PTSD conditional risk associated with specific traumatic events that survivors of Yazidi women and girls faced. The highest percentage among age groups of the study sample was the age (18->29) years and the mean of ages were (28.5). This result is close to Tekin et al (2016), they studied Prevalence and gender differences in symptomatology of posttraumatic stress disorder and depression among Iraqi Yazidies displaced 
into Turkey, and they found that the mean of age among females was (31.9). This age group is used more by ISIS militants because they represent the adulthood period of age and they have been use for serving the militants and as for satisfying their physical and sexual needs.

Different salvation methods have been used to rescue the Yazidi women and girls from ISIS army, the most used methods were redemption (47.07) and personal escape (38.4). Different tragedian stories have been told by the survivors and the obstacles, difficulties, and risks that they have been through during their attempts to escape from ISIS army; also large sums of money have been paid for redemptions.

The majority of the samples (80.7) have lost at least one member of their families during the ISIS attack; some of them have lost all the family members. ISIS army attacked the families with no exceptions to children, women, or even to elderly people.

Two different types of violence with high percentages have been directed to study sample; physical violence was about (76.9) and sexual violence about (61.5). Hassen (2016), also showed that ISIS have used multiple forms of sexual and gender-based violence such as torture, abduction, slavery, systemic rape and other heinous crimes against the Yazidi women and their families. Other studies by Commandeur (2015), Callimachi (2015), Moran (2016), and Powell (2017) showed that ISIS has used the Yazidi women as 'slaves' for sexual exploitation. The majority of the physical and sexual violence that have been directed to the samples were made by more than one assaulter (84.6). ISIS militants are using gang rape and battering as a torture and punishment toward Yazidis women and girls for their escaped attempts; they also exchange their Sabaya each few days with other militants or sell them in slaves market. The study sample have recorded high percentage (75.0) of PTSD symptoms, this result goes with Tekin et al (2016), they found that participants with current PTSD (74.5\%) were female, but is different from the results of Tekin et al (2015) in which they assessed the Prevalence of PTSD and depression among Iraqi Yazidi refugees, their frequency result of PTSD was 42.9\%, also Nickerson et al (2010) studied The impact of fear for family on mental health in a resettled Iraqi refugee community, their Study sample recorded substantial rates of PTSD (29\%), and another study about Psychiatric symptoms and disorders among Yazidi children and adolescents immediately after forced migration following ISIS attacks was made by Ceri et al (2016), they got only $(10.5 \%)$ for posttraumatic stress disorders. These low percentages of PTSD symptoms are because both studies have been made directly after ISIS attack, PTSD assessment needs at least 
six months to be diagnosed, and the sample are the refugees not the survivors, but in this study the sample are only the survivors; they have faced and witnessed different kinds of trauma, also few years passed after ISIS attack, so it's not surprising to have such high percentages of PTSD symptoms after the years of traumas and stressful life events with ISIS army.

\section{Conclusions:}

The study concluded that the majority of survivors from ISIS army are aged from (18->29) years old, the most used and successful methods of salvation that been used was redemption and personal escape. The majority of the survivors have lost at least one family member since the ISIS attack in 2014. Most of the sample exposed to physical and sexual violence by more than one assaulter, and high percentages of PTSD symptoms was reported due to the traumas that they have faced since ISIS attack.

\section{Recommendations:}

Combined with the current study results, other previous studies, and existing evidence, national and international interventions is needed for the survivors to meet their physical and psychological needs, further studies about other mental and psychological disorders are needed to be assessed immediately, and these estimates are need to be considered as genocide against Kurdish community by an appointed judicial authority.

\section{Acknowledgement:}

Great appreciation to: Yazidi organizations and offices for their support in this study, to the Yazidi women and girls for participating in this study, and to the best friend Rajab Assi Karim for his guide and support.

\section{References:}

Andrykowski, M. A., Cordova, M. J., Studts, J. L., \& Miller, T. W. (1998). Posttraumatic stress disorder after treatment for breast cancer: Prevalence of diagnosis and use of the PTSD Checklist-Civilian Version (PCL-C) as a screening instrument. Journal of consulting and clinical psychology, 66(3), 586.

Asmundsin, G.J.G., Barnhofer, T., Blackmore, M.A., Collimore, K.C., Daniel, J., Fennell, M.J.V., et al. (2009). Cognitive behaviour therapy: A guide for the practicing clinician ;(2). New York, NY: Routlege.

Atwoli, L., Stein, D. J., Koenen, K. C., \& McLaughlin, K. A. (2015). Epidemiology of posttraumatic stress disorder: prevalence, correlates and consequences. Current Opinion in Psychiatry, 28(4), 307-311. http://doi.org/10.1097/YCO.0000000000000167 
Buzany, K. (2017). Statistics of Yazidis after ISIS war since 2014. Yazidis Affairs Office, Arbil, Kurdistan region, Iraq. khairi_bozani@yahoo.com 009647504676173).

Breslau, N., Kessler, R. C., Chilcoat, H. D., Schultz, L. R., Davis, G. C., \& Andreski, P. (1998). Trauma and posttraumatic stress disorder in the community: the 1996 Detroit Area Survey of Trauma. Archives of general psychiatry, 55(7), 626-632.

Brewin, C. R., Andrews, B., \& Valentine, J. D. (2000). Meta-analysis of risk factors for posttraumatic stress disorder in trauma-exposed adults.

Callimachi, R. (2015). ISIS enshrines a theology of rape. The New York Times, A1.

Carr, V.J., Lewin, T.J., Webster, R.A., et al. (1995). Psychosocial sequelae of the 1989 Newcastle earthquake: I. Community disaster experiences and psychological morbidity 6 months postdisaster. Psychol Med; (25):539-55.

Carrion, V. G., Weems, C. F., Ray, R., \& Reiss, A. L. (2002). Toward an empirical definition of pediatric PTSD: The phenomenology of PTSD symptoms in youth. Journal of the American Academy of Child \& Adolescent Psychiatry, 41(2), 166-173.

Ceri, V., Özlü-Erkilic, Z., Özer, Ü., Yalcin, M., Popow, C., \& Akkaya-Kalayci, T. (2016). Psychiatric symptoms and disorders among Yazidi children and adolescents immediately after forced migration following ISIS attacks. neuropsychiatrie, 30(3), 145-150.

Chanda, P. O. (2016). The evolution of rape: A deadly weapon of war in a cyber world (Doctoral dissertation, Utica College).

Commandeur, G. (2015) .An analysis of the sexual exploitation of Yazidi women by Islamic State of Iraq and Syria (ISIS) and Christian women by Boko Haram: Spoils of war, holy war, or instrumental gain?

Davis, L. (2016). Iraqi Women Confronting ISIL: Protecting Women's Rights in the Context of Conflict.

Friedman, M. J. (2014). PTSD: National Center for PTSD. PTSD History and Overview.

Galea, S., Nandi, A., Vlahov, D. (2005).The Epidemiology of Post-Traumatic Stress Disorder after Disasters. Epidemiol Rev : 27 (1): 78-91. doi: 10.1093/epirev/mxi003

Grohol, M. J. (2017). A quick PTSD screening tool. From Psychcentral, in $29^{\text {th }}$ November 2017 https://psychcentral.com/quizzes/ptsd-quiz.htm

Gupta, M. A. (2013). Review of somatic symptoms in post-traumatic stress disorder. International review of psychiatry, 25(1), 86-99.

Hassen, S. H. (2016). Investigating Sexual and Gender-Based Violence as a Weapon of War and a Tool of Genocide against Indigenous Yazidi Women and Girls by ISIS in Iraq (Doctoral dissertation).

Johnson, H., \& Thompson, A. (2008). The development and maintenance of post-traumatic stress disorder (PTSD) in civilian adult survivors of war trauma and torture: A review. Clinical psychology review, 28(1), 36-47. 
Lang et al. (2012). Abbreviated PTSD Checklist (PCL) as a guide to clinical response. Original Research Article General Hospital Psychiatry, 34, 332-338.

Lang, A.J., Stein, M.B. (2005). An abbreviated PTSD checklist for use as a screening instrument in primary care. Behavior Research and Therapy, 43, 585-594.

Mancini, M. (2016). The Fury of ISIS Against Ethnic and Religious Minorities: The Genocide of the Yazidis. Diritti umani e diritto internazionale, (3), 619-644.

McCausland, C. (2017). From Tolerance to Tactic: Understanding Rape in Armed Conflict as Genocide.

Moran, M. J. (2016). Trafficked into War. Investigating the case of the Islamic State of Iraq and the Levant, how do women and girls continue to be disproportionately vulnerable to sex trafficking and systematic rape in periods of armed conflict and civil unrest? (Master's thesis).

Möller, A., Söndergaard, H. P., \& Helström, L. (2017). Tonic immobility during sexual assault-a common reaction predicting posttraumatic stress disorder and severe depression. Acta obstetricia et gynecologica Scandinavica.

Nickerson, A., Bryant, R. A., Steel, Z., Silove, D., \& Brooks, R. (2010). The impact of fear for family on mental health in a resettled Iraqi refugee community. Journal of psychiatric research, 44(4), 229-235.

Ozer, E. J., Best, S. R., Lipsey, T. L., \& Weiss, D. S. (2003). Predictors of posttraumatic stress disorder and symptoms in adults: a meta-analysis. Psychological bulletin, 129(1), 52.

Powell, C. (2017). Rape as a Tactic of Terror: Holding the Islamic State Accountable.

Scott, K.M., Koenen, K.C., Aguilar-Gaxiola, S., et al. (2013) Associations between lifetime traumatic events and subsequent chronic physical conditions: a cross-national, cross-sectional study. PLoS One ;(8): 850-73.

Shalev, A. Y., Freedman, S., Peri, T., Brandes, D., Sahar, T., Orr, S. P., \& Pitman, R. K. (1998). Prospective study of posttraumatic stress disorder and depression following trauma. American Journal of Psychiatry, 155(5), 630-637.

Tekin, A., Karadag, H., Suleymanoglu, M., Tekin, M., \& Alpak, G. (2015). Prevalence of PTSD and depression among Iraqi Yazidi refugees. Klinik Psikofarmakoloji Bulteni, 25.

Tekin, A., Karadăg, H., Süleymanoğlu, M., Tekin, M., Kayran, Y., Alpak, G., \& Şar, V. (2016). Prevalence and gender differences in symptomatology of posttraumatic stress disorder and depression among Iraqi Yazidis displaced into Turkey. European Journal of Psychotraumatology, 7, 10.3402/ejpt.v7.28556. http://doi.org/10.3402/ejpt.v7.28556

UN, Human Right Council. (13 ${ }^{\text {th }}$ June 2017). A report about Yazidis in Iraq after ISIS. Canton of Geneva, Swiss.

Van Etten, M. L., \& Taylor, S. (1998). Comparative efficacy of treatments for post-traumatic stress disorder: a meta-analysis.

Wilson, J. P., Friedman, M. J., \& Lindy, J. D. (Eds.). (2012). Treating psychological trauma and PTSD. Guilford Press. 
تعريف بعض الصدمات و اضطراب مابعد الصدمة بين الناجيات من النساء اليزيديات من عنف داعث

نازدار قرت عباس

تمريض صحة نفسية و عقلية

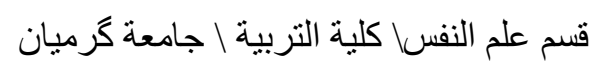

Nazdar.qudrat@garmian.edu.krd

- - - الخلاصة

الخلفية: العنف ضد المراة تبقى واحدة من اكبر التحديات في وقتنا هذا, العنف الجنسي اثناء الحروب المسمى

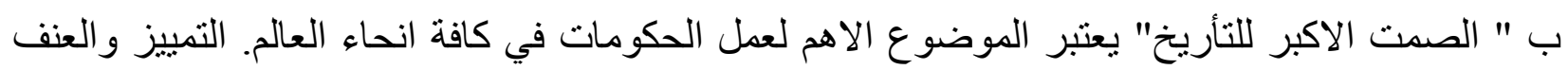
الذي تعرضن له نساء وبنات اليزيديات من قبل تنظيم داعش في سنجار 2014, يعتبر من ابشع واخطر مأساة عالمية في هذا العصر. تعرض اليزيديون وبالاخص نسائهم للكثير من الصدمات و المصاعب الجسدية

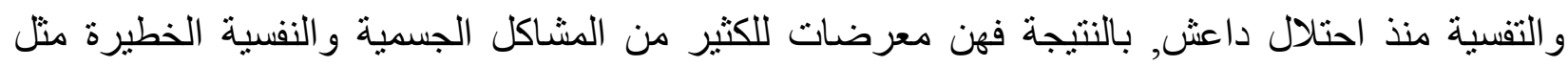
اضطر اب مابعد الصدمة, الكابّة والانتحار, واضطر ابات الاكل والنوم. تهذف الدراسة الحالية الى تسليط

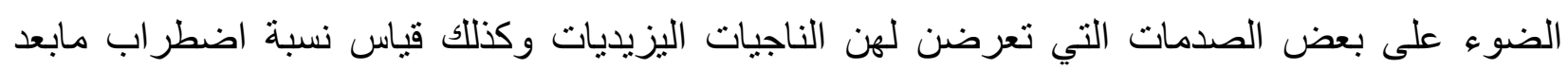
الصدمة بين الناجيات. الطريقة: در اسة وصفية تكونت من (52) ناجية بزيدية تم اختبار هن بطريقة غرضية,

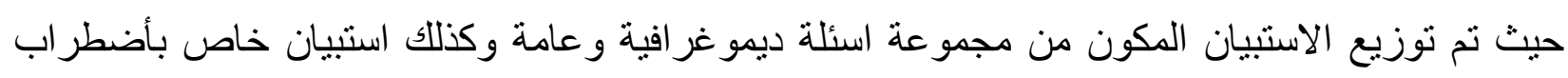
مابعد الصدمة, للفترة من ايلول الى تشرين الثناني 2016, في مخيمات اللاجئين اليزيديين في دهوك, وني ونم تحليل البيانات بطريقة وصفية بأستخام برنامج (SPSS. 22). النتائج: اظهرت النتائج الكثير نسب عالية من الصدمات التي تعرضت لهن الناجيات, (38.4)هربن بصعوبة من يد داعش, (80.7) خسرن عالاقل شخص و احد من عو ائلهن, (76.9) نعرضن لعنف جسدي, (61.5) تعرضن لعنف جنسي, (84.6) تعرضن لعنف من اكثر من شخص و احد, و (75.0) لديهن اعر اض اضطر اب مابعد الصدمة. التوصيات: التداخلات المحلية و الدولية ضرورية بالاخص للناجيات من العنف الجنسي, الدعم الجسدي, الاجتماعي, والنفسي ضروري, وكذللك در اسات وبحوث اخرى في المستقبل ضرورية لتقييم معاناتهم وتقييم الامر اض النفسية المحتملة فيهن. الكلمات الدالة: داعش, الصدمة, اضطر اب مابعد الصدمة, الناجيات اليزيديات 